\title{
An attempt to estimate the competency gap in the IT sector
}

\author{
Paweł Lula, Renata Oczkowska, Sylwia Wiśniewska, Katarzyna Wójcik
}

\section{A B S T R A C T}

Objective: The aim of this article is to determine whether there is a gap between the demand for competencies of graduates of the computer science major and their supply.

Research Design \& Methods: Identification of the key set of competencies required by employers from job applicants and estimation of the competency gap in the IT sector was conducted using the method of exploratory analysis of job offers for positions related to the administration of IT systems.

Findings: The results of the preliminary research shown that proposed method can be used for estimation of competency gap however it requires more experiments.

Contribution \& Value Added: Proposition of new method for competency gap calculation based on exploratory analysis of data available in the Internet.

\begin{tabular}{lll}
\hline Article type: & research paper \\
Keywords: & competency; competency gap; labour market; IT sector; Latent \\
& Dirichlet Analysis & \\
JEL codes: & J40, C51, C63 & \\
\hline \multicolumn{1}{c}{ Article received: 4 September 2019 } & Article accepted: 1 December 2019 \\
\hline
\end{tabular}

\section{Suggested citation:}

Lula, P., Oczkowska, R., Wiśniewska, S. \& Wójcik, K. (2019). An attempt to estimate the competency gap in the IT sector. International Entrepreneurship Review (previously published as International Entrepreneurship / Przedsiębiorczość Międzynarodowa), 5(3), 95-112. https://doi.org/10.15678/IER.2019.0503.07

\section{INTRODUCTION}

The functioning of contemporary companies and their demand for labour change very rapidly. The technological growth and innovations lead to changes in the structure of the demand for labour, but also to modification of the labour market segmentation. The dynamics of changes in the labour market is increasingly faster, which also means a quick outdating of the existing competencies and a growing demand for new competencies, especially in the IT sector. Changes in the content and methods of work cause consequences in the knowledge and ability to use new technologies or new IT tools. An imbalance appears in the demand and supply of competencies, which, in turn, affects the functioning of enterprises. In general, employers are looking for employees with competencies different from 
those possessed by job-seekers. This phenomenon, constituting the difference between the required and the possessed competencies, is called the competency gap.

Many reasons for the occurrence of the competency gap may be indicated. The most frequent reason for its presence lays in the intersectoral structural transformations. Emerging branches often lack qualified employees capable of meeting the requirements of positions related to modern technologies. The competency gap may be deepened by the teaching programmes being ill-adjusted to the needs of the labour market. Therefore, it is particularly important for the enterprise competitiveness to monitor the demand for competencies, including identification of trends regarding changes of the demand for labour. It thus becomes significant to create possibilities of identifying the employer demand for professional qualifications and the supply of qualifications earned in various forms of learning and certification of the achieved results of learning. This would allow employers to acquire competent employees and would facilitate evaluation or modification of the results of learning and education earned in various educational institutions, above all, at universities, focused on the needs of the labour market. This approach would also help people who are studying plan their personal and professional development.

The aim of this article is to determine whether there is a gap between the demand for competencies of graduates of the computer science major and their supply. The presence of the competency gap would indicate that this market is imperfect and requires the application of appropriate corrective mechanisms enabling reduction in these disproportions, resulting in larger satisfaction of the employers' demand for competencies of graduates of IT majors at universities.

Identification of the key set of competencies required by employers from job applicants in the IT sector was conducted using the method of exploratory analysis of job offers for positions related to the administration of IT systems, posted on the website pracuj.pl. On the other hand, the self-evaluation of competencies of IT students was conducted in the form of an on-line survey among 200 students of the applied computer science major of the Cracow University of Economics.

On the basis of the research, it can be determined whether and to what extent studies at the applied computer science major of the CUE correspond to the expectations of the labour market, and thus whether and to what extent a competency gap exists.

\section{LITERATURE REVIEW}

\section{The essence of competencies}

The literature on the subject does not agree as to what the professional competencies of employees are. The multiplicity of approaches results mainly from the fact that the issue of competencies is analysed by specialists representing different scientific disciplines: management, psychology and sociology.

The issue of competencies began to be considered in literature at the turn of the $1960 \mathrm{~s}$ and 1970s, which was reflected in publications of White and McClelland. However, deeper interest in competencies was initiated in the 1980 s by Boyatzis, who defined competencies as the capacity of a given person to display behaviours compliant with the requirements of the job position specified by the organizational environment parameters, which, in turn, 
yields the desired results (Armstrong, 2011). Furthermore, Boyatzis (2008) brings attention to the fact that demonstration of competencies at work is affected by the organization of a given business activity, namely: culture, structure, maturity of a given organization, and the position of the contractor. The environment is also significant, which is determined by the following aspects: economic, political, social, religious, and environmental. However, in any case the level of competencies, but also the possibility to their development, is determined by: proficiency and professional experience, recognized knowledge, procedural knowledge, functional knowledge, as well as the possession of certain cognitive skills, ensuring independent execution of a new task, and related to memory, identification of dependencies, deduction. In the opinion of Boyatzis, competencies may differ, and the level of their diversity is shaped by: cognitive competencies, such as system thinking and recognized behaviour patterns, competencies related to emotional intelligence, including self-awareness, self-control, as well as social competencies, including social awareness and management of mutual relations through empathy and teamwork. The notion of competencies in the concept of Boyatzis thus assumes taking into consideration the sphere of work motivation, work variability, its performance - especially the possibility to raise or adapt to increasingly higher standards of work performance.

A similar employee-oriented approach is presented by Thierry, Sauret \& Monod (1994). They define competencies as the employee's capacity to take action leading to achievement of the intended goal under specific conditions, using specific means. Furthermore, competencies are the entire knowledge, skills, experience, attitudes, and the employee's readiness to act under particular conditions, and thus also the ability to adapt to these changing conditions.

One of the supporters of competencies being considered from the perspective of the employee is also Armstrong (2000), who believes that competencies are the potential contributing to the achievement of specific results. Remaining in this trend, Oleksyn (2006) defines employee competencies broadly as their interests, abilities and dispositions, education and knowledge, experience and practical skills, internal motivation, attitudes and behaviours important in professional work, health and psychophysical condition, formal equipment with the right to act on behalf of a given organization, professed values and ethical principles. $A$ broad definition of competencies is also presented by Pocztowski (2007), who brings attention to the fact that it is a notion wider than qualifications, covering all permanent features of a human, creating a causal relation with the achieved high or outstanding work results, which can be measured. It is worth referring to the notion of qualifications, which cover the employee's capacity to perform a specific job confirmed by relevant documents, e.g. diplomas, school certificates or documented work experience. However, the possession of qualifications does not determine the possession of competencies. At the same time, it is necessary to have personality traits, attitudes and behaviours that enable proper use of the available knowledge and skills in effective implementation of entrusted tasks.

In the previously presented perspectives, competencies are examined from the point of view of the employee, which is the so-called American approach. However, competencies are also connected with the position. This, in turn, is the so-called British concept, which was created for the needs of the National Vocational Qualifications project (NVQs), which was aimed at better adjustment of educational programmes to the needs of the 
labour market, focuses on the job position and on defining tasks and effects from the point of view of the requirements set by particular workplaces for their contractors.

In the Polish reality, this approach is represented by Król (2006), who understands competencies as dispositions with regard to knowledge, skills and attitudes, ensuring implementation of professional tasks at an effective or outstanding level, according to standards specified by the organization for a given job. Currently, the more widespread depiction of competencies in theory and practice of management is the American one. This approach provides significantly more possibilities of adapting to changing situations. Flexibility in adapting to situations, to a specific and variable organizational context, results in the fact that competencies are revealed while performing a specific work. Professional work usually requires continuous updating of competencies. This applies particularly to functioning in conditions of uncertainty and variability, which is associated with choices and making decisions, and not only with workmanship, where activities have the nature of an algorithm.

In connection with the presented discussion, it can be stated that, in the Polish reality, competencies are examined both in relation to the employee and the job position. However, it should be emphasized that many authors consider both concepts at the same time. The mixed approach is represented, among others, by Filipowicz (2004). In his opinion, competencies are predispositions with regard to knowledge, skills and attitudes, allowing for pursuance of professional objectives at an appropriate level. A similar perspective is presented by Rostkowski, who acknowledges that competencies are knowledge, skills, predispositions, and attitudes of employees, which - when used during work - help implement the organization's strategy (Juchnowicz ed., 2014).

To sum up the above considerations, it can be stated that the mixed concept of understanding competencies from the perspective of the employee and the job position is complete and correct. Undoubtedly, the conformity of competencies with the job requirements is a necessary condition for an effective process of improvement in the quality of work (Nowakowska et al., 2011). Furthermore, the definitions of competencies presented in the subject literature are not homogeneous, they are interpreted differently and consist of various components. However, it may be considered that the key elements of competencies are knowledge, skills and attitudes, which - when used during work - help implement the organization's strategy.

\section{Typology of competencies}

The subject literature includes various typologies of competencies. Among the most popular is the classification of Katz (1974). He distinguishes the following types of competencies:

- technical - they are necessary for current work and for solving technical problems, making decisions requiring specialist knowledge, as well as support for employees with small professional experience. They cover, among others: specialist knowledge within a given field, knowledge concerning methods of work, production processes, procedures and technologies, as well as the ability to use technical equipment,

- social - they constitute proper behaviour in relations with other people (superiors, subordinates, co-workers or clients). This category includes such competencies as: building of relations, sensitivity, communication skills, understanding of motivations and attitudes of other people, as well as diplomatic approach. These competencies determine the social position of a given person and the strength with which he/she influences others, 
- conceptual - they refer to analysis and synthesis of data, formulation of conclusions, capacity to make the right decisions and creative problem-solving, as well as prediction of changes, noticing of opportunities or creation of action plans. They are of key importance in the process of defining and implementing strategies in particular areas of operations.

Furthermore, Katz assigned the aforementioned types of competencies to particular levels of management. Therefore, he indicated dependencies between the employee's position in the organization and the competency categories necessary for effective work on the given organizational hierarchy level. According to this author, for people starting their management career, the most important elements are predispositions in the area of social and technical competencies. Such persons should have competencies within their field, should be able to win people over and affect their work. Along with the development of the career to the level of middle-level managerial staff, social competencies gain importance and technical competencies lose importance. At this level, it is very important to build teams, exert influence and motivate to reliable work. Knowledge of technical aspects of work performed by subordinates is less important. The middle level of management is also where the need for using conceptual competencies appears, which are necessary for planning, solving complex and unique problems, as well as for decision-making in a situation of uncertainty. On the other hand, in the case of the highest level of management, conceptual competencies are of critical importance for the success of the conducted activities. However, technical competencies completely lose their importance. Management staff at the highest level is responsible for creation and implementation of the operation strategy and, when necessary, benefits from the aid of advisors.

A complex typology of competencies is suggested by Delamare Le Deist \& Winterton (2005), who - under an original model of competencies - divided them into:

- cognitive - related to openness, curiosity, the ability to learn, understand and memorize. High level of these competencies is possessed by people who are not susceptible to the influence of others. They are crucial in childhood and youth, although curiosity and passion for learning can be the human domain through his/her entire life,

- functional - are necessary for effective work in a given profession and on a given position,

- social - involve interpersonal relations and are expressed in the ease in establishing and maintaining contacts, ability to balance different views and interests, solve conflicts and cooperate, e.g. as part of implementation of common goals,

- meta-competencies - on the one hand, they concern the ability to reflect and learn, while on the other hand, the ability to cope in conditions of uncertainty, which is presently gaining importance.

Another classification of competencies, prepared by Filipowicz (2014), refers to the division of competencies in the perspective of Katz and Delamare Le Deist \& Winterton. This author distinguishes four basic categories of competencies:

- social - determining the quality performed tasks associated with contacts with people (e.g. commercial contacts). The level of these competencies determines the effectiveness of communication, cooperation and influencing other people. Sample social competencies include, among others: communication skills, teamwork, building of relations, sharing of knowledge and experience, 
- personal - related to performance of tasks by the employee, and their level affects the quality of the performed tasks. They also determine the adequacy in actions and the speed of their performance. Personal competencies include, among others: innovativeness, entrepreneurship, flexibility, own work organisation, self-management during a period of time, problem-solving, and stress management,

- managerial - involve human resource management, both with soft areas of management, work organisation, as well as with strategic aspects of management. The effectiveness of management of the organisation's employees is determined by the level of these competencies. Exemplary personal competencies include, among others: analytic thinking, strategic thinking, motivating, delegation of tasks, team-building,

- professional (specialist, technical) - concern specialist tasks set for particular groups of positions. They are often connected with specific scopes of knowledge or skills. The level of these competencies is reflected in the effectiveness of implementation of tasks typical of a given profession, position or performed function. Examples of personal competencies include: process management, project management, professional knowledge, the ability to use modern information technologies.

A different typology of competencies is presented by Juchnowicz (2014). In her opinion, the types of competencies most often distinguished in the subject literature include:

- transferable - affecting the effectiveness of actions in various professional situations. They enable full use of the qualification potential and professional experience of a given person. Transferability of these competencies means the possibility of their "transfer" and successful application in a different (new) professional or personal situation,

- specific - covering a given scope of knowledge, skills, experience, abilities necessary for performance of tasks on a given position and in a given profession. They have a narrow scope and are rich in terms of content. They include complex specialist skills, based on higher education or rich professional experience, necessary for performing complicated work.

The ambiguity when defining the notion of competencies determines the diversity of competency categories. The subject literature contains many classifications of competencies, prepared on the basis of various criteria. The most widely indicated competencies include: professional, non-professional, soft, hard, personal, social, objective, and subjective (table 1).

To sum up the above discussion, it can be stated that the typology of competencies presented in the subject literature are not homogeneous. The classification of competencies including social, personal, managerial and professional will be used as the basis of analysis in the research.

\section{Competency gap and its estimation}

The functioning of contemporary companies and their demand for labour change very rapidly. Technological growth and innovations lead to changes in the structure of demand for labour, but also to modification of the segmentation on the labour market. The dynamics of changes in the labour market become faster and faster, which also means quick outdating of the existing competences and growing demand for new competences. An imbalance appears in the demand and supply of competences, which, in turn, affects the operation of enterprises. In general, employers are looking for employees with competences differing 
Table 1. Characteristics of different types of competencies

\begin{tabular}{|c|c|c|}
\hline Item & Types of competencies & Characteristics \\
\hline \multirow{2}{*}{1} & Professional & $\begin{array}{l}\text { They enable undertaking work in a given profession, as well as promo- } \\
\text { tion and professional success. They enable performance of profes- } \\
\text { sional duties as required by a given position. }\end{array}$ \\
\hline & Non-professional & $\begin{array}{l}\text { They constitute the basis for professional competencies. They are also } \\
\text { useful in activities unrelated to professional work. They include, among } \\
\text { others: immunity to stress, establishing contacts, responsibility. }\end{array}$ \\
\hline \multirow[t]{2}{*}{2} & Soft & $\begin{array}{l}\text { They are universal for most jobs and mainly concern self-management } \\
\text { and relations with the environment (including other people). They in- } \\
\text { clude, among others: teamwork, communication skills, managing } \\
\text { emotions, entrepreneurship, assertiveness. }\end{array}$ \\
\hline & Hard & $\begin{array}{l}\text { They allow for practicing a given profession and performing tasks on } \\
\text { a given position. They cover specialist knowledge and skills typical of } \\
\text { the specific specialization. }\end{array}$ \\
\hline \multirow[t]{2}{*}{3} & Personal & $\begin{array}{l}\text { They characterize the person and demonstrate his/her uniqueness. } \\
\text { They cover, among others, knowledge, skills, abilities, habits, atti- } \\
\text { tudes, tastes, temper, adaptability. They enable performance of activ- } \\
\text { ities from various scopes, contributing to achievement of professional } \\
\text { and personal objectives. }\end{array}$ \\
\hline & Social & $\begin{array}{l}\text { They are shaped and expressed in social interactions. They determine } \\
\text { the nature of the relations of a given person with other people. They } \\
\text { concern creation of good interpersonal relations. }\end{array}$ \\
\hline \multirow{2}{*}{4} & Objective & $\begin{array}{l}\text { An internally consistent system of predispositions and properties } \\
\text { that enables an effective and ethical performance of duties, re- } \\
\text { gardless of who performs them. They determine the standards } \\
\text { for particular competencies for the needs of professions, special- } \\
\text { izations, job positions, roles performed in the organization. They } \\
\text { are helpful in maintaining objectivity in the recruitment process } \\
\text { and the assessment of employees. }\end{array}$ \\
\hline & Subjective & $\begin{array}{l}\text { Competencies actually possessed by a given person, which can be di- } \\
\text { agnosed as a result of an individual assessment. They consist of phys- } \\
\text { ical and mental features, possessed knowledge and skills, abilities, in- } \\
\text { terests, principles, adopted attitudes and styles of action, which are } \\
\text { used and developed within professional activity. The subjective aspect } \\
\text { of competencies results from their dependence on the specific nature } \\
\text { of a person, who uses them throughout the performance of tasks. }\end{array}$ \\
\hline
\end{tabular}

Source: prepared by the authors on the basis of: (Jeruszka, 2016; Baron-Puda, 2008).

from those owned by the people looking for jobs. This phenomenon, meaning the difference between required and possessed competences, is called the competence gap (Oczkowska, Wiśniewska \& Lula 2017).

In Poland competency gap estimation analysis is done within the Study of Human Capital (pl. Bilans Kapitału Ludzkiego) research project which is one of the biggest research projects oriented to demand and supply of competences on labour market in Europe. In this type of research mainly surveys addressed to employers and employees are used. Also job offers are a very important source of information about employers 
expectations. In Study of Human Capital in Poland the evaluation of candidates competences was done in a way of a self-assessment of certain competences level of unemployed and jobseekers (Czarnik et. al. 2019).

\section{MATERIAL AND METHODS}

\section{The formula for competency gap estimation}

The estimation of competency gap was the main goal of the research. It was assumed that the measure of the competency gap should reflect the diversity between employers' expectations towards candidates and competencies possessed by candidates. Using the classification presented in table 1 the competency gap can be considered as the difference between objective competencies representing job requirements necessary to obtain certain position and subjective competencies representing candidates characteristics. The process of competency gap evaluation was composed of the following steps:

1. Identification of the list of the key competencies:

$$
\boldsymbol{C}=\left[C_{1}, C_{2}, \ldots, C_{N}\right]
$$

2. Evaluation of the employers' expectations towards candidate competencies $\left(\boldsymbol{C}^{E}\right.$ - expected competencies). They were defined as a distribution of the employers' expectations over key competencies:

$$
\boldsymbol{C}^{E}=\left[p_{E}\left(C_{1}\right), p_{E}\left(C_{2}\right), \ldots, p_{E}\left(C_{N}\right)\right]
$$

where: $p_{E}\left(C_{i}\right)$ can be interpreted as the probability of the occurrence of the $C_{i}$ competency in the employers' expectations. For elements of the $\boldsymbol{C}^{E}$ vector it is guaranteed that: $\sum_{i=1}^{N} p_{E}\left(C_{i}\right)=1$. Value of $p_{E}\left(C_{i}\right)$ can be treated as a measure of the importance of the $C_{i}$ competency for employers.

3. Evaluation of competencies possessed by candidates ( $\boldsymbol{C}^{P}-$ possessed competencies) which can be defined as:

$$
\boldsymbol{C}^{P}=\left[p_{P}\left(C_{1}\right), p_{P}\left(C_{2}\right), \ldots, p_{P}\left(C_{N}\right)\right]
$$

The $\boldsymbol{C}^{P}$ describes the distribution of the candidates' evaluation of their own competencies over the key competencies. For $p_{P}\left(C_{i}\right)$ also we have: $\sum_{i=1}^{N} p_{P}\left(C_{i}\right)=1$.

4. Calculation of the competency gap $(c g)$ as a value of the average Kullback-Leibler divergence between $\boldsymbol{C}^{E}$ and $\boldsymbol{C}^{P}$ distributions:

$$
c g=\frac{K L\left(\boldsymbol{C}^{E}, \boldsymbol{C}^{P}\right)+K L\left(\boldsymbol{C}^{P}, \boldsymbol{C}^{E}\right)}{2}
$$

where $K L\left(f^{1}, f^{2}\right)$ is a measure of the Kullback-Leibler divergence between distributions given by $f^{1}$ and $f^{2}$.

The formula (4) shows that the evaluation of competency gap should be preceded by the estimation of $\boldsymbol{C}^{E}$ and $\boldsymbol{C}^{P}$ distributions.

\section{The evaluation of the competencies expected by employers}

The evaluation of competencies expected by employers was realized by the analysis of job offers published by employers in pracuj.p/ web site (one of the most popular Polish portal with job offers). The contents of offers published at the portal allowed to identify key competen- 
cies expected by employers and to estimate their importance (represented by the $\boldsymbol{C}^{E}$ distribution). For solving these two tasks the Latent Dirichlet Allocation method was used (Blei, $\mathrm{Ng}$ \& Jordan, 2003). During the analysis the following sequence of steps was performed:

1. Offers retrieval from the pracuj.p/ portal.

This task was realized with the aid of the rvest package (Wickham, 2016), available in the $R$ system. Offers retrieved from the portal had a form of HTML documents. In our research we used offers from the section "IT - Administration".

2. Identification of offer sections containing competency description.

This part of an offer had the form of a list of employer's expectations towards a potential candidate. It has been assumed that every item taken from employer expectation lists is related to one desirable competency. For further analysis every list item derived from offer descriptions was processed as a separate document.

3. The use of the Latent Dirichlet Alloction (LDA) algorithm on the corpus containing documents items retrieved from lists of employer expectations.

The $L D A$ algorithm allows to identify topics represented in the corpus of documents. Every $L D A$ topic is defined as a probability distribution over words (terms) occurring in the whole corpus.

To present crucial elements of the $L D A$ algorithm we have a corpus $\boldsymbol{D}$ with $L D$ documents:

$$
\boldsymbol{D}=\left[\begin{array}{lll}
d_{1} & \ldots & d_{L D}
\end{array}\right]^{T}
$$

and we can assume that the dictionary $\boldsymbol{V}$ is available (vector of all words in a corpus):

$$
\boldsymbol{V}=\left[\begin{array}{lll}
v_{1} & \ldots & v_{L V}
\end{array}\right]^{T}
$$

The use of the $L D A$ algorithm allows to identify a set $\boldsymbol{T}$ of $L T$ topics:

$$
\boldsymbol{T}=\left[\begin{array}{lll}
t_{1} & \ldots & t_{L T}
\end{array}\right]^{T}
$$

which are present in documents from the corpus $\boldsymbol{D}$.

Every topic is defined by a probability distribution over words taken from the dictionary $\boldsymbol{V}$. The matrix $\boldsymbol{\Phi}$ defines all topics represented in the corpus $\boldsymbol{D}$ :

$$
\boldsymbol{\Phi}=\left[\begin{array}{ccc}
\phi_{1,1} & \cdots & \phi_{1, L V} \\
\cdots & \cdots & \cdots \\
\phi_{L T, 1} & \cdots & \phi_{L T, L V}
\end{array}\right]
$$

Values $\phi_{i, j}$ represents the probability of occurrence on the $j$-th word in the $i$-th topic. Whereas the matrix $\Theta$ informs about the contribution of every topic to every document:

$$
\boldsymbol{\Theta}=\left[\begin{array}{ccc}
\theta_{1,1} & \cdots & \theta_{1, L T} \\
\cdots & \cdots & \cdots \\
\theta_{L D, 1} & \cdots & \theta_{L D, L T}
\end{array}\right]
$$

Elements $\theta_{i, j}$ indicate the probability of occurrence of $j$-th topic in the $i$-th document.

The process of the LDA model creation incorporates the estimation of $\boldsymbol{\Phi}$ and $\boldsymbol{\Theta}$ matrices with the help of available set of documents (represented by the corpus $\boldsymbol{D}$ ). During the research presented in the paper, this process was performed with the help of the topicmodels package (Grün \& Hornik, 2011) available for the $R$ system.

4. Evaluation of the $L D A$ topic importance in a given job offer. 
Assumptions related to the form of the corpus (which was not defined as a set of job offers but as a set of list items describing employers' expectations) caused that matrix $\mathbf{\Theta}$ describes the contribution of $L D A$ topics not in offers, but in list items. Therefore it is necessary to aggregate topics' importance over job offers. The schema of required calculation was presented in Table 1.

Table 2. Evaluation of LDA topics' importance for a given job offer

\begin{tabular}{|c|c|c|c|c|}
\hline \multirow{3}{*}{ Job offer } & $\begin{array}{c}\text { List items related } \\
\text { to a given job offer }\end{array}$ & Topic 1 & $\ldots$ & Topic $\boldsymbol{L T}$ \\
\hline \multirow{6}{*}{$k$} & $d_{1}$ & $\theta_{1,1}$ & $\ldots$ & $\theta_{1, L T}$ \\
\cline { 2 - 5 } & $d_{2}$ & $\theta_{2,1}$ & $\ldots$ & $\theta_{2, L T}$ \\
\cline { 2 - 5 } & $d_{3}$ & $\theta_{3,1}$ & $\ldots$ & $\theta_{3, L T}$ \\
\cline { 2 - 5 } & $\ldots$ & $\ldots$ & $\ldots$ & $\ldots$ \\
\cline { 2 - 5 } & $d_{n}$ & $\theta_{n, 1}$ & $\ldots$ & $\pi_{n, L T}$ \\
\cline { 2 - 5 } & $O_{k}$ & $\pi_{k, 1}=\max _{i}\left(\theta_{i, 1}\right)$ & $\ldots$ & $\ldots$ \\
\end{tabular}

Source: own study.

It was assumed that the importance of the $j$-th $L D A$ topic in the $k$-th job offer is represented by a maximum value taken from $\theta_{i, j}$ where $i$ represents all list items occurring in the $k$-th offer.

5. Evaluation of the $L D A$ topic importance in the whole set of offers.

Having values $\pi_{k, j}$ describing the contribution of the $j$-th topic in the $k$-th offer it was possible to estimate the importance of every $L D A$ topic in the whole set of all job offers. The schema of calculation is presented in the Table 2.

Table 3. Evaluation of LDA topics' importance for the set of all job offers

\begin{tabular}{|c|c|c|c|}
\hline Job offer & Topic 1 & $\ldots$ & Topic $\boldsymbol{L T}$ \\
\hline 1 & $\pi_{1,1}$ & $\ldots$ & $\pi_{1, L T}$ \\
\hline 2 & $\pi_{2,1}$ & $\ldots$ & $\pi_{2, L T}$ \\
\hline$\ldots$ & $\ldots$ & $\ldots$ & $\ldots$ \\
\hline$K$ & $\pi_{K, 1}$ & $\ldots$ & $\pi_{K, L T}$ \\
\hline The set of all job offers & $\omega_{1}=\frac{\sum_{k=1}^{K} \pi_{k, 1}}{\sum_{t=1}^{L T} \omega_{t}}$ & $\ldots$ & $\omega_{L T}=\frac{\sum_{k=1}^{K} \pi_{k, L T}}{\sum_{t=1}^{L T} \omega_{t}}$ \\
\hline
\end{tabular}

Source: own study.

The importance of the $j$-th LDA topic in the whole set of offers is expressed by a $\omega_{j}$ value. The formula used for its calculation guarantees that the sum of all value $\omega_{i}$ is equal one. It allows to interpret obtained values as the distribution of the offer content over a set of $L D A$ topics.

6. Identification of key competencies and evaluation of their importance.

It is worth to underline that topics discovered by the LDA algorithm may not represent key competencies required by employers. Very often more than one LDA topic can be treated as a component of the same competency (for example more than one LDA topic can be related to one key competency understood as "competency in computer system security" or "competency in IT project management"). 
First, for every $L D A$ topic, the interpretation was identified. This process was based on the analysis of words with the highest probability of occurrence in the definition of a given topic. Next $L D A$ topics were grouped to form key competencies. Topics related to the same competency were included into the same cluster representing one competency. Taking into account the fact that job offers were prepared in Polish or in English language, the LDA algorithm discovered topics with the same meaning, but based on words taken from these two different languages. Such topics also were merged into the same groups. The expert knowledge related to the IT sphere was used as the basis for the key competency discovery process. As it was mentioned identified competencies were classified into social, personal, managerial and professional groups.

The analysis presented above allowed to discover $N$ key competencies defined in the formula (1).

The $q$-th key competency can be treated as a subset of the $\boldsymbol{T}$ set.

$$
C_{q}=\left\{t_{1}, t_{2}, \ldots, t_{Q}\right\} \subseteq \boldsymbol{T}
$$

where $t_{j}$ represents $L D A$ topic used as component of the $C_{q}$ competency.

For two key competencies $C_{q}$ i $C_{r}$ we have:

$$
C_{q} \cap C_{r}=\varnothing
$$

The importance for employers of the $C_{q}$ competency can be defined as:

$$
I^{E}\left(C_{q}\right)=\sum_{s} \omega_{s}
$$

where $s$ indicates $\angle D A$ topics included in the definition of the $C_{q}$ competency.

The vector $\left[I^{E}\left(C_{1}\right), I^{E}\left(C_{2}\right), \ldots, I^{E}\left(C_{N}\right)\right]$ is normalized and can be used as an assessment of the employers' expectations towards candidate competencies (represented by the $\boldsymbol{C}^{E}$ distribution):

$$
\boldsymbol{C}^{E}=\left[I^{E}\left(C_{1}\right), I^{E}\left(C_{2}\right), \ldots, I^{E}\left(C_{N}\right)\right]
$$

and plays the crucial role in the process of evaluation of competency gap.

\section{The evaluation of the competencies possessed by potential employees}

The assessment of the competencies possessed by potential employees was performed with the use of a questionnaire in which every key competency was evaluated on 5-point Likert scale. In the survey key competencies identified with the use of the LDA method were used. For every competency respondents evaluated two aspects:

- respondent's evaluation of the competency importance for potential candidates on the job market,

- possession of a given competency by a respondent.

In the presenting study a self-evaluation approach was used for the competency evaluation. But we are convinced that the same method of analysis can be used when candidates' competencies are estimated in different way (for example by the use of survey among experts). The use of the Likert scale for competency assessment is the only requirement which must be fulfilled.

The following procedure was used: 
1. Evaluation of competencies made by respondents with the use of the 5-point Likert scale. Taking into account that the number of key competencies is $N$, for every respondent a vector of grades was defined:

$$
\boldsymbol{e}_{s}=\left[e_{s, 1}, e_{s, 2}, \ldots, e_{s, N}\right]
$$

where $e_{s, q}$ is an evaluation of the $q$-th competency made by the $s$-th respondent. All $e_{s, q}$ values were expressed on the 5-points Likert scale.

2. Creation of individual preference matrices showing comparative evaluation of key competencies performed by every respondent. The individual preference matrix created for the $s$-th respondent had a form:

$$
P_{S}=\left[\begin{array}{ccc}
p_{1,1}^{S} & \cdots & p_{1, N}^{S} \\
\cdots & \cdots & \cdots \\
p_{N, 1}^{S} & \cdots & p_{N, N}^{S}
\end{array}\right]
$$

where $p_{q, r}^{S}$ is a measure of preferences between $C_{q}$ and $C_{r}$ competencies expressed on the Saaty scale (Saaty, 2008). To calculate the $p_{q, r}^{s}$ element of the preference matrix values $e_{s, q}$ and $e_{s, r}$ were used:

$$
p_{q, r}^{s}=\left\{\begin{array}{cl}
\frac{9}{5} \times \frac{e_{s, q}}{e_{s, r}} & \text { if } e_{s, q}>e_{s, r} \\
1 & \text { if } e_{s, q}=e_{s, r} \\
\frac{1}{\frac{9}{5} \times \frac{e_{s, r}}{e_{s, q}}} & \text { if } e_{s, q}<e_{s, r}
\end{array}\right.
$$

3. Creation of the aggregated preference matrix. Presented above individual preference matrices were calculated for every respondent. In the current step of the analysis these matrices were used for the creation of the aggregated preference matrix $\boldsymbol{P}$ which had a form:

$$
\boldsymbol{P}=\left[\begin{array}{ccc}
p_{1,1} & \cdots & p_{1, N} \\
\cdots & \cdots & \cdots \\
p_{N, 1} & \cdots & p_{N, N}
\end{array}\right]
$$

The aggregation process was performed with the use of the geometric mean formula:

$$
p_{q, r}=\left(\prod_{s=1}^{L S} p_{q, r}^{S}\right)^{\frac{1}{L S}}
$$

where $L S$ is equal to the number of all respondents.

4. Assessment of the competency importance with the use of the aggregated preference matrix. The matrix $\boldsymbol{P}$ calculated in the previous step was used as a starting point for calculation of weights expressing key competency importance. Weights were calculated as a normalized eigenvector corresponding to the highest eigenvalue of the $\boldsymbol{P}$ matrix:

$$
I^{P}\left(C_{q}\right)=\frac{\varepsilon_{q}}{\sum_{i=1}^{N} \varepsilon_{i}}
$$

where $\varepsilon_{q}$ indicates the $q$-th element of the eigenvector of the $\boldsymbol{P}$ matrix corresponding to the highest eigenvalue. Values $I^{P}\left(C_{q}\right)$ were used as the evaluation of competencies possessed by candidates. They can be treated as elements of the $\boldsymbol{C}^{P}$ vector:

$$
\boldsymbol{C}^{P}=\left[I^{P}\left(C_{1}\right), I^{P}\left(C_{2}\right), \ldots, I^{P}\left(C_{N}\right)\right]
$$


Values defined in formulas (13) and (20) allow do calculate the competency gap with the use of the formula (4).

\section{Introduction of the data sources}

Key competencies and their importance for employers were identified by the analysis of 1618 job offers retrieved from the portal pracuj.pl (section: IT Administration). The list of the key competences is shown in the Table 3

Table 3. Key competencies identified by the analysis of job offers published in the pracuj.pl

\begin{tabular}{|c|l|}
\hline Competency ID & \multicolumn{1}{|c|}{ Competency description } \\
\hline$C_{01}$ & Information systems administration \\
\hline$C_{02}$ & Project Management \\
\hline$C_{03}$ & Computer systems security \\
\hline$C_{04}$ & Programming \\
\hline$C_{05}$ & Information Systems Design \\
\hline$C_{06}$ & Customer support systems \\
\hline$C_{07}$ & $\begin{array}{l}\text { Commitment, analytical thinking, ability to work in a team, ability to work under } \\
\text { a time pressure }\end{array}$ \\
\hline$C_{08}$ & Knowledge of the English language \\
\hline$C_{09}$ & Data Analyst \\
\hline$C_{10}$ & Databases \\
\hline$C_{11}$ & University degree in IT \\
\hline$C_{12}$ & Office software \\
\hline
\end{tabular}

Source: own study.

The competencies of students were analyzed by the use of the self-assessment questionnaire filled by 192 students of the "Applied Informatics" program at Cracow University of Economics. Almost $50 \%$ of respondents were 3rd year 1st degree students and over $20 \%$ were 1st year 2 nd degree students (Figure 2.). These is the time when most of the IT students in Poland seek for their first job or at least first job in IT.

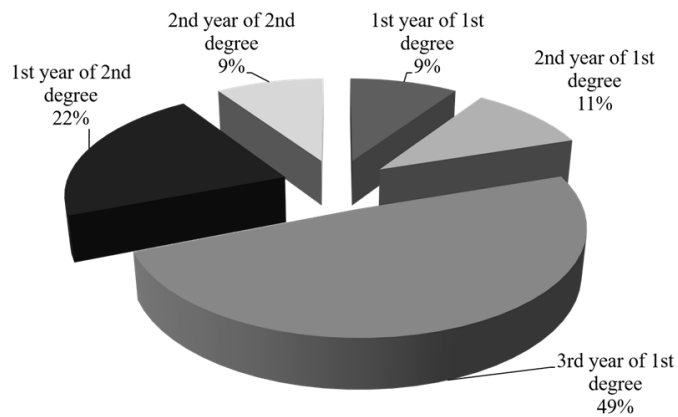

Figure 1. Characteristics of respondents - year and degree of study Source: own elaboration.

Most of respondents (about 90\%) were full-time students. Most of the part-time and over a half of the full-time students are already working and most of employed ones has job compatible with their education (Figure 3.). 
Do the respondents work

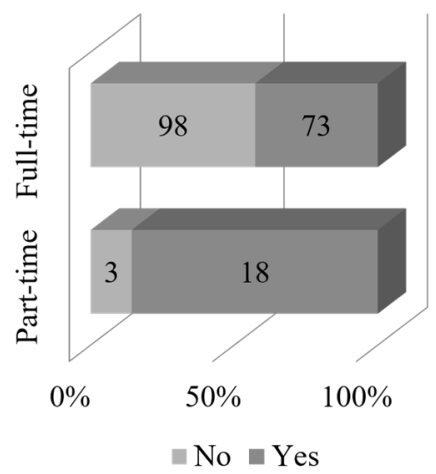

Is their job compatible with their education

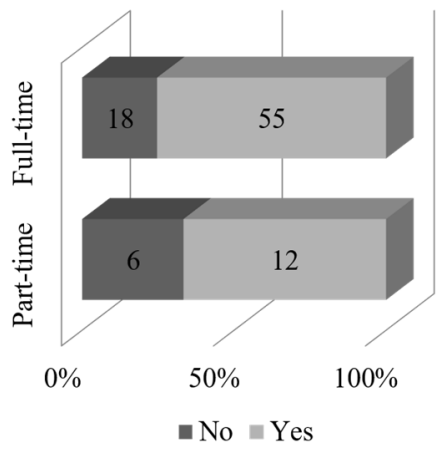

Figure 2. Characteristics of respondents - employment status by form of study Source: own elaboration.

In questionnaire every respondent was asked to evaluate the competency importance for potential candidates and the degree in which he/she possess a given competency. These two aspects were analyzed separately. Students were asked to evaluate only competences presented in Table 3 identified as the most important for employers in "IT Administration" field.

\section{RESEARCH RESULTS}

The method proposed in the previous section of the paper was used for the evaluation of the competency gap between employers' expectations in the "IT Administration" field and competencies possessed by students of the "Applied Informatics" study program at the Cracow University of Economics. Figure 1 presents the importance of key competencies identified by the analysis of job offers published in the pracuj.pl portal which was the first phase of research.

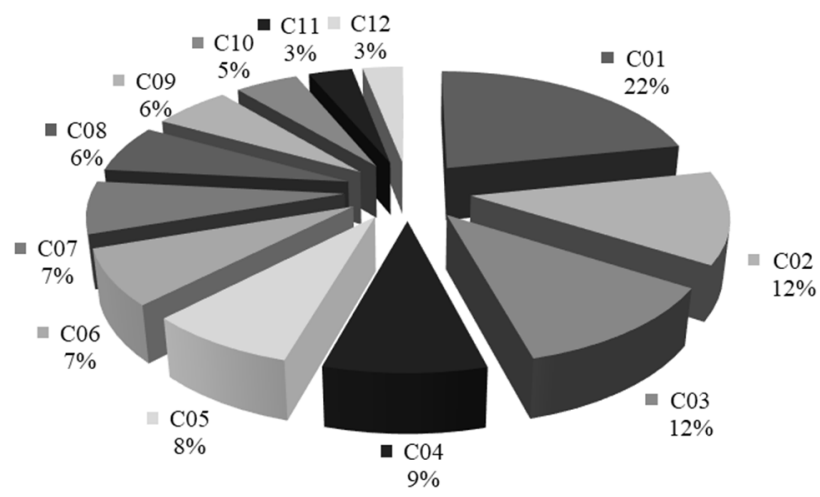

Figure 3. The importance of key competencies identified by the analysis of job offers published in the pracuj.pl portal Source: own elaboration. 
In second stage of research the answers to questionnaire were analyzed. First the analyses of competency importance made by respondents were studied. The results are presented in the Figure 4.

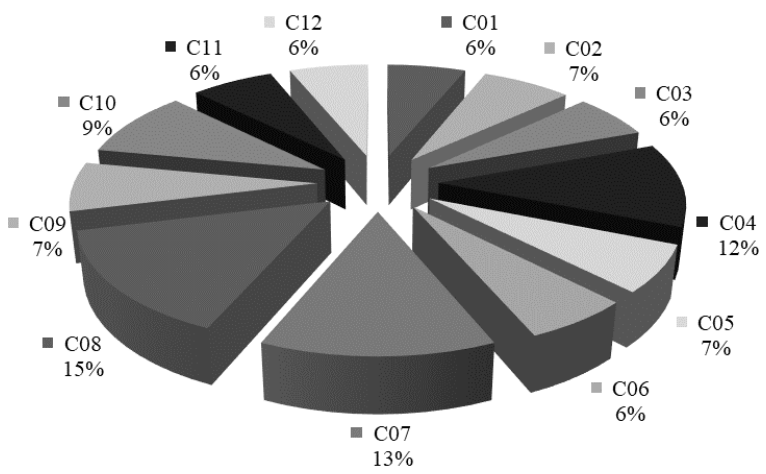

Figure 4. The evaluation of key competency importance calculated on the basis of students opinions

Source: own elaboration.

The competency gap between employers' expectations and students opinions about competency importance calculated as an average Kullback-Leibler divergence was equal to 0,2302 . This measure can be treated as a pseudo distance between two distributions (it is not a distance because it does not satisfy the triangular inequality) which always belongs to the range $[0,+\infty]$.

In the survey respondents also were asked to evaluate their own competencies (in the scope represented by key competencies). The results are shown in the Figure 5.

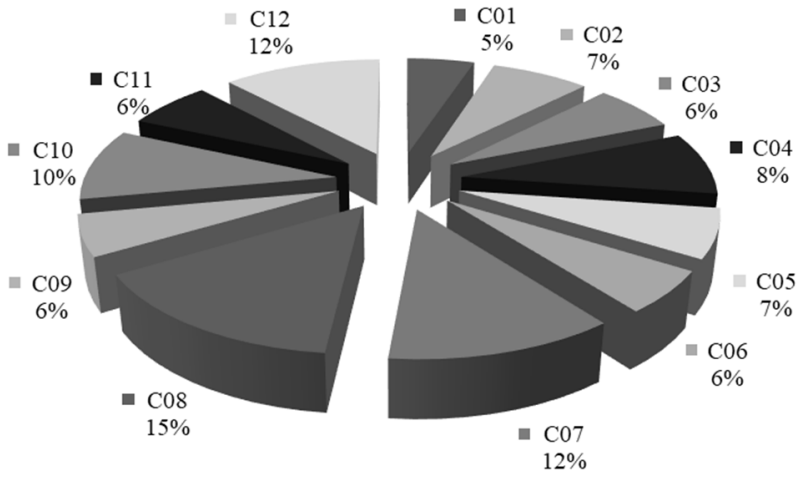

Figure 5. The evaluation of respondents' competencies calculated on the basis of students opinions Source: own elaboration.

The competency gap between employers' expectations and students opinions about their own competencies in the scope covered by key competencies is equal to 0,2928 . Also the gap between students evaluation of competencies importance and students evaluation of 
their own competencies was calculated. It was equal to 0,027 . The results of the analysis show that students opinions about their own competencies are very close to their opinions about ideal competencies for candidates looking for a job in the IT sector. Unfortunately, students evaluations are rather far from expectations of employers expectations expressed in job offers (Figure 6).

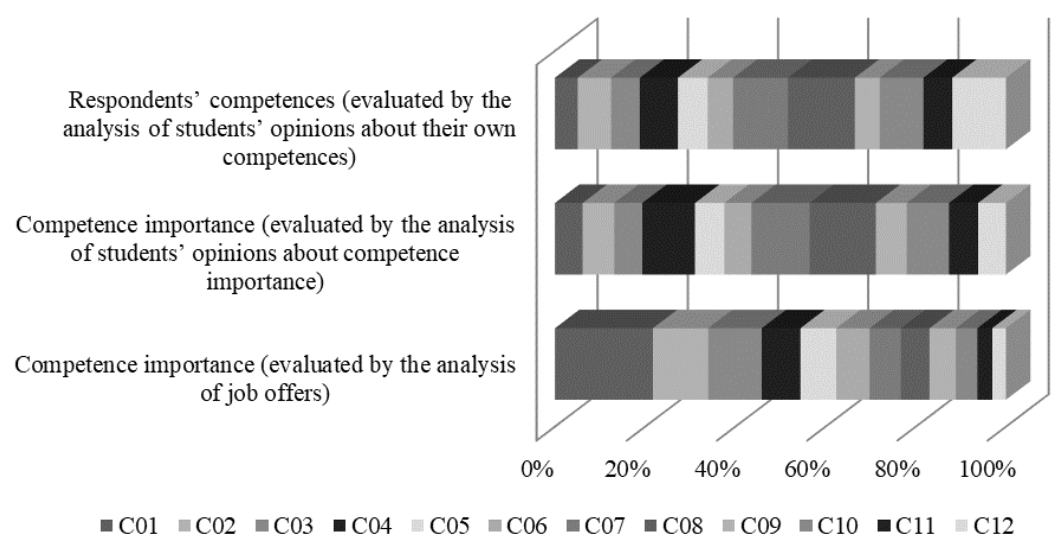

Figure 6. Comparison of different evaluations of the key competencies Source: own elaboration.

\section{CONCLUSIONS}

The results of the preliminary research shown that proposed method can be used for estimation of competency gap however it requires more experiments. The respondents of the questionnaire were Applied Informatics students at Cracow University of Economics who are entering the job market. It is necessary to repeat experiment on wider range of students e.g. from different universities located not only in Cracow. Also it is worth considering to use of the method for different fields of studies and different job offers sections.

To evaluate the correctness of obtained results authors are planning to invite recruiters and HR departments employees to determine what is real competencies demand and what is their opinion about competencies of candidates applying for job in their institutions.

Separate task that is planned is comparison of job requirements and students competencies with study programs to evaluate how well study programs prepare graduates for entering the job market.

\section{REFERENCES}

Armstrong, M. (2011). Zarzq̨dzanie zasobami ludzkimi. Warszawa: Oficyna Wolters Kluwer Business. Baron-Puda, M. (2008). Zapotrzebowanie na pracowników w przedsiębiorstwach produkcyjnych. Zarzqdzanie Zasobami Ludzkimi, (3-4), 126-135.

Blei, D., Ng, A. \& Jordan, M. (2003). Latent Dirichlet Allocation. Journal of Machine Learning Research, (3), 993-1022.

Boyatzis, R.E. (2008). Competencies in the 21st century. Journal of Management Development, 27 (1), 5-12. 
Czarnik, S., Górniak, J., Jelonek, M., Kasparek, K., Kocór, M., Lisek, K., Prokopowicz, P., Strzebońska. A., Szczucka, A., Worek, B. (2019). Bilans Kapitału Ludzkiego - Aktywność zawodowa i edukacyjna dorosłych Polaków wobec wyzwań współczesnej gospodarki-Raport podsumowujqcy VI edycję badania BKL w latach 2017-2018. Warszawa: Polska Agencja Rozwoju Przedsiębiorczości, Uniwersytet Jagielloński.

Delamare Le Deist, F., \& Winterton, J. (2005). What is competence?. Human Resource Development International, 8(1), 27-46.

Filipowicz, G. (2004). Zarzq̨dzanie kompetencjami zawodowymi. Warszawa: PWE.

Filipowicz, G. (2014). Zarzqdzanie kompetencjami: Perspektywa firmowa i osobista. Warszawa: Oficyna a Wolters Kluwer business.

Grün, B. \& Hornik, K. (2011). Topicmodels: An R Package for Fitting Topic Models. Journal of Statistical Software, 40(1), 1-30.

Heinrich, G. (2004). Parameter estimation for text analysis, http://www.arbylon.net/publications/text-est.pdf; 02.01.2018.

Jeruszka, U. (2016). Kompetencje. Aspekty teoretyczne i praktyczne. Warszawa: Difin.

Juchnowicz, M. (ed.). (2014). Zarzqdzanie kapitałem ludzkim. Procesy - narzędzia-aplikacje. Warszawa: PWE.

Juchnowicz, M. (2014). Sektorowe badania podaży i popytu na kwalifikacje i kompetencje. Edukacja Ekonomistów i Menedżerów. Problemy. Innowacje. Projekty, 2(32), 11-19.

Katz, R.L. (1974). Skills of an effective administrator. Harvard Business Review, 52(5), 90-102.

Król, H., \& Ludwiczyński, A. (ed.). (2006). Zarzqqdzanie zasobami ludzkimi. Warszawa: Wydawnictwo Naukowe PWN.

Nowakowska, I., Głowacka, M.D., Rasińska, R., \& Głowacka-Rębała A. (2011). Zarządzanie jakością pracy członków organizacji. Problemy Zarzq̨dzania, 9(4), 217-225.

Oczkowska, R., Wiśniewska, S. \& Lula. P. (2017). Analysis of the Competence Gap Among Vocational School Graduates in the Area of Smart Specialization in Poland. International Journal for Quality Research, 11(4), 945-966.

Oleksyn, T. (2006). Zarzqdzanie kompetencjami: Teoria i praktyka. Kraków: Oficyna Wydawnicza.

Pierścionek, Z. (1998). Strategie rozwoju firmy. Warszawa: PWN.

Pocztowski, A. (2007). Zarzqqdzanie zasobami ludzkimi. Warszawa: PWE.

Saaty, T.L. (2008). Decision making with the analytic hierarchy process. International Journal of Services Sciences, 1(1), 83-98.

Sławiński, S. (ed.). 2011. Słownik kluczowych pojęć zwiqzzanych z krajowym systemem kwalifikacji. Warszawa: IBE.

Thierry, D., Sauret, Ch., \& Monod, N. (1994). Zatrudnienie i kompetencje w przedsiębiorstwach w procesie zmian. Warszawa: Poltext.

Wickham, H. (2016). Package 'rvest', https://cran.r-project.org/web/packages/rvest/rvest.pdf; 02.01.2018. 


\section{Authors}

The contribution share of authors is equal and amounted to $25 \%$ each of them.

\section{Paweł Lula}

He obtained a doctoral degree and a habilitation degree at the Cracow University of Econom-ics. His research interests include data analysis methods and tools, information technology, artificial intelligence, methods of web, graph and text mining.

Correspondence to: Prof. Paweł Lula, PhD, Cracow University of Economics, ul. Rakowicka 27, 31-510 Krakow, Po-land, e-mail: pawel.lula@uek.krakow.pl

ORCID (1) http://orcid.org/0000-0003-2057-7299

\section{Renata Oczkowska}

She obtained a doctoral degree and a habilitation degree at the Cracow University of Economics. Her research interests include employee competencies, labour market, globalization and internationalization of enterprises.

Correspondence to: Prof. Renata Oczkowska, PhD, Cracow University of Economics, ul. Rakowicka 27, 31-510 Kra-kow, Poland, e-mail: renata.oczkowska@uek.krakow.pl

ORCID (1) http://orcid.org/0000-0001-5936-6398

\section{Sylwia Wiśniewska}

She obtained a doctoral degree at the Cracow University of Economics. Her research interests include employability, employee competencies, labour market and diversity management.

Correspondence to: Sylwia Wiśniewska, PhD, Cracow University of Economics, ul. Rakowicka 27, 31-510 Krakow, Poland, e-mail: sylwia.wisniewska@uek.krakow.pl

ORCID (1) http://orcid.org/0000-0003-4760-2634

\section{Katarzyna Wójcik}

She obtained a master's degree at the Cracow University of Economics. Her research interests include data mining, text mining, opinion mining, competencies analysis and widely defined data analysis.

Correspondence to: Katarzyna Wójcik, MSc, Cracow University of Economics, ul. Rakowicka 27, 31-510 Krakow, Poland, e-mail: katarzyna.wojcik@uek.krakow.pl

ORCID (1) http://orcid.org/0000-0002-4431-5245

\section{Acknowledgements and Financial Disclosure}

The Project has been financed by the Ministry of Science and Higher Education within "Regional Initiative of Excellence" Programme for 2019-2022. Project no.: 021/RID/2018/19. Total financing: 11897131.40 PLN.

\section{Copyright and License}

This article is published under the terms of the Creative Commons

Attribution - NoDerivs (CC BY-ND 4.0) License

http://creativecommons.org/licenses/by-nd/4.0/

Published by the Centre for Strategic and International Entrepreneurship - Krakow, Poland 